\title{
PENGARUH AJARAN GNOSTIK DALAM KEKRISTENAN DITINJAU DARI PERSPEKTIF SEJARAH GEREJA
}

\author{
Oleh : Pdt. Dr. Jon Mister R. Damanik, D.Th \\ Dosen Pasca Sarjana STT Erikson - Tritt
}

\begin{abstract}
ABSTRAK
Ajaran gnostik adalah suatu ajaran yang mengajarkan tentang penyangkalan karya Allah di bumi ini, juga menyangkal karya keselamatan dari Tuhan Yesus Kristus. Ajaran gnostik pada yang lahir abad ke 2 berusaha meracuni pemikiran manusia supaya tidak percaya kepada Tuhan dan menyelewengkan kebenaran. Padahal jika ditelusuri bahwa pengajaran gnostik bersumber dari Alkitab tetapi mereka skeptis terhadap kebenaran yang ada dalam Alkitab. Tetapi dalam perjalanannya bahwa ajaran gnostik ini tidaklah bertahan hingga saat ini karena gereja-gereja pada masa itu mengatakan bahwa gnostik itu menyimpang dari ajaran Tuhan.

Tidaklah dapat disangkali bahwa jemaat Tuhan berkali-kali mendapatkan tantangan baik dalam fisik seperti penganiayaan maupun dalam pengajaran. Tidaklah menyurutkan kepercayaan mereka kepada Tuhan dapat dikatakan bahwa darah syahid adalah benih gereja itu terbukti bahwa kesetiaan orang-orang Kristen pada masa itu memberikan teladan dan banyak orang menjadi percaya kepada Yesus. Rasul Paulus di hadapan Agripa dalam menyampaikan kesaksiannya dan diakhir kesaksiannya Kisah Para Rasul 26:28 jawab Agripa:"hampir-hampir saja kau yakinkan aku menjadi Kristen! Dan Paulus menjawab: Aku berdoa kepada Allah supaya segera atau lama bukan engkau saja, tetapi semua orang lain yang hadir di sini dan mendengarkan perkataanku menjadi sama seperti aku, kecuali
\end{abstract}


belenggu-belenggu ini. Suatu perkataan yang indah disaat dalam keadaan yang sulit bahwa nama Yesus selalu dikumandangkan.

\section{Kata Kunci : Ajaran Gnostik, Kekristenan, Sejarah Gereja}

\section{PENGARUH AJARAN GNOSTIK DALAM KEKRISTENAN DITINJAU DARI PERSPEKTIF SEJARAH GEREJA}

Perkembangan jemaat Tuhan pada masa itu tidaklah mudah, jika diteliti dalam Alkitab sejarah pertumbuhan jemaat Tuhan mendapatkan tantangan yang luar biasa, baik itu dari agama Yahudi yang di dalamnya ada golongan Farisi dan Saduki yang mengatakan apa yang diajarkan oleh Yesus itu adalah sesat dan tidak sesuai dengan normanorma ajaran Yudaisme baik juga dari kerajaan Romawi. Dalam Alkitab dijelaskan setelah khutbah rasul Petrus (Kis. 2:14-40) dan ayat 41mengatakan bahwa "orang-orang yang menerima perkataannya itu memberi diri dibaptis dan pada hari itu jumlah mereka bertambah kirakira tiga ribu jiwa." Inilah yang menjadi awal perkembangan kekristenan pada abad pertama.

Dalam perjalanan perkembangan kekristenan di muka bumi ini, banyak mengalami hambatan-hambatan yang ingin melumpuhkan kekristenan terlebih pada pada masa kekaisaran Romawi yang mulai dilakukan pada:

"Tahun 64 Masehi pemerintahan Kaisar Nero, kebakaran besar terjadi di Roma selama enam hari enam malam api berkobarkobar, sebagian besar kota menjadi abu, desas-desus berkembang bahwa Nero sendirilah yang menyebabkan kota Roma dilalap api ini membangkitkan kebencian besar terhadap kaisar itu. Untuk mengalihkan kebencian itu dari dirinya, maka Nero menuduh orang-orang Kristen yang telah membakar kota Roma. Tuduhan itu tentu saja tidak benar, tetapi sejumlah besar orang Kristen telah ditangkap dan diikuti oleh panganiayaan yang mengerikan banyak orang Kristen disalibkan. Beberapa orang dijahit dalam kulit binatang-binatang buas kemudian 
anjing-anjing besar dibiarkan dilepaskan untuk menyerang mereka dan mereka dikoyak-koyak menjadi potonganpotongan daging, para wanita diikat pada sapi-sapi gila dan diseret-seret sampai mati, setelah malam tiba orang Kristen dibakar di kayu sula di dalam taman milik Nero. Orang-orang Roma yang membenci orang Kristen bebas datang ke taman itu dan Nero duduk di kereta perangnya menikmati pemandangan yang mengerikan itu."

Diringkaskan bahwa penganiayaan yang dilakukan oleh orang yang membenci orang-orang Kristen berlangsung hingga 312 Masehi dan pada tahun 313 Masehi Kontantinus Agung mengeluarkan dekrit milan yang isinya menghentikan segala bentuk penganiayaan terhadap orang-orang Kristen.

Selain itu hal yang menjadi pembahasan dalam tulisan ini adalah ajaran Gnostik yang juga menjadi hambatan yang sangat besar dalam perkembangan agama Kristen dan gnostik ini sudah ada pada saat sebagian kitab-kitan dalam perjanjian baru ditulis salah satu nasehat Paulus terhadap Timotius supaya berhati-hati dalam gnostik hal ini tertuang dalam kitab 1 Timotius 6:20 yang mengatakan:"Hai Timotius, peliharalah apa yang telah dipercayakan kepadamu. Hindarilah omongan yang kosong dan yang tidak suci dan pertentanganpertentangan yang berasal dari apa yang disebut pengetahuan.

Gnostikisme adalah salah satu aliran yang sangat berpengaruh pada abad pertama dan kedua, dan puncak pengaruhnya ada pada tahun 150 M. Tokoh penting dalam ajaran Gnostik ini adalah "Valentius" Istilah Gnostikisme berasal dari bahasa Gerika "Gnosis" yang mempunyai arti "Pengetahuan." Pengetahuan yang dimaksud adalah "Hikmat tinggi yang rahasia dan tersembunyi mengenai asal-usul dan tujuan hidup manusia. Menurut pengikut aliran ini, bahwa: hanya orang rohani yang dapat memasuki rahasia itu dan dapat dipuaskan dan mengerti. Gnostikisme, berkembang pada masa zaman rasul-rasul juga pada zaman Paulus. 1 Timotius 6:20; 1 Yohanes 4:1-3, juga pada jaman kitab Yudas.

Dasar penekanan yang terkandung dalam ajaran gnostikisme menyatakan bahwa gnostikisme merupakan sistem filsafat yang dibangun di atas dasar filsafat Yunani yang menekankan bahwa materi

${ }^{1}$ B. K. Kuiper, The Church In History (Malang: Penerbit Gandum Mas, 2010), hlm. 15-16. 
adalah jahat sedangkan roh adalah baik, oleh karena itu Allah tidak mungkin telah menciptakan dunia materi ini."2

\section{Perkembangan Dan Ajaran Gnostik}

Pengikut ajaran Gnostikisme, mereka mengaku bahwa mereka mempunyai pengetahuan yang jauh lebih tinggi tentang asal dunia, tabiat manusia, secara khusus mengenai asalnya kejahatan. Mereka membentuk sistem filsafat yang dapat membebaskan Allah dari ciptaan-Nya dari kejahatan. Apa yang dimaksud dengan filsafat? Filsafat lahir dari kata Philos dan Shopia. Philos artinya berpikir sedangkan Shopia adalah kebijaksanaan. Berpikir artinya mengolah data inderawi menjadi pengertian atau proses mencari makna. Maka filsafat dapat diartikan berpikir tentang data inderawi dan pengambilan keputusan yang memihak kepada pihak yang lemah."3 Lahirnya filsafat itu datang dari keragu-raguan (skeptis), maka lahirnya ajaran gnostik ini adalah dari keragu-keraguan mereka dalam menerima apa yang dikatakan oleh Alkitab dari keragu-raguan mereka mencoba merumuskan suatu rumusan berdasarkan pemikiran tentang data inderawi tentang Allah, maka muncullah suatu rumusan tentang Allah, Yesus, Roh Kudus, bumi menurut merka benar.

\section{Ajaran Gnostikisme}

Pertama, Allah sebagai Roh tak ada hubungan apa-apa dengan dunia ialah tertinggi dari segala sesuatu. (bandingkan dengan ajaran Epikurus).

Kedua, dunia dijadikan oleh makhluk yang lebih rendah dari Allah yang bernama Demiurgos (yang berarti pencipta dunia). Dunia penuh dengan penderitaan pasti tidak mungkin diciptakan oleh Allah yang baik. Allah adalah terang yang dikelilingi oleh malaikat-malaikat yang rohani dan murni. Demiurgos adalah salah satu pancaran dari Allah. Makin banyak pancaran makin banyak zat duniawi yang dikandung di

${ }^{2}$ Paul Enns, The Moody Handbook Of Theology (Malang: Literatur SAAT, 2016), hlm. 2:34

${ }^{3}$ Dr. Darsono Prawironegoro, SE, SF, MA, MM, Filsafat Ilmu (Jakarta: Nusantara Consulting, 2011), hlm. 15. 
dalamnya. Demiurgos bercampur zat ilahi dan zat benda, sehingga ia beroleh kuasa untuk menciptakan dunia. Demiurgos dipersamakan oleh aliran gnostik dengan Allah dalam Perjanjian Lama, dan mereka tidak suka pada Allah itu. Demikianlah terjadinya dua Allah. Pencipta adalah Allah Perjanjian Lama yang jahat, dan penyelamat Perjanjian Baru yang baik. Siapakah yang mengenal Yesus terlepas dari genggaman Allah Perjanjian Lama.

Ketiga, manusia mengandung sebagaian kecil dari Roh Allah di dalam batinnya.

Keempat, Kristus diutus ke dalam dunia oleh Allah dengan tubuh maya (khayal yang sebenarnya tidak ada, hanya gambar angan-angan saja). Untuk membebaskan sebagian kecil Roh di dalam manusia. Oleh karena zat benda dianggap jahat, mereka tidak dapat menghubungkan Kristus dengan daging manusia. Tubuhnya hanya kelihatan sebagian khayal saja. Tetapi sebenarnya tidak ada. Kristus telah meninggalkan orang bernama Yesus sewaktu Yesus disalibkan.

Kelima, dengan pelajaran dan teladan Kristus roh manusia diajak berusaha melepaskan dirinya dari zat benda yang jahat agar kembali kepada Allah yang tinggi.

Keenam, dengan jalan askese (siksa diri) segala pengetahuan atau gnosis, yang tersembunyi telah terbuka tetapi hanya kepada orang rohani bolehlah ia mengerti atau bergnosis. Jalan memperoleh gnosis melalui pembacaan Alkitab secara alegoris. Hanya orang rohani menurut ukuran gnosis yang dapat membebaskan zat ilahi kecil dalam hidupnya serta melepaskan dirinya dari hal-hal fana, dan boleh dipersatukan dengan zat Allah yang tertinggi."4

Selain dari ajaran ini dari golongan gnostik selalu berusaha dengan kemampuan mereka untuk meyakinkan para pengikutnya dalam mengikuti ajaran mereka ini, dan berusaha menyelewengkan ajaran yang sebenarnya. Selain dari hal di atas bagian bagian yang gnostik lakukan adalah menciptakan kitab-kitab lain. Seperti yang dikemukakan oleh Th. Van Den End:

"Penganut-penganut gnostik menyusun beberapa kitab "Injil" antara lain "Injil Thomas" di dalamnya terdapat kata-kata Yesus yang asli, tetapi kata-kata itu digarap sedemikian rupa hingga membenarkan pandangan-pandangan gnostik, namun

${ }^{4}$ Dr Dietrich Kuhl, Sejarah Gereja (Batu: YPPII, 1997), hlm. 2:20. 
disamping bahan-bahan yang asli itu ditemukan pula bermacam-macam dongeng mengenai Yesus. Penganutpenganut gnostik mengatakan bahwa di dalam kitab-kitab Injil itu termuat hikmat rahasia yang kata mereka dipercayakan oleh Kristus hanya kepada murid-murid-Nya yang paling akrab dan yang karena itu tidak terdapat dalam kitab Injil-injil biasa, membuktikan keaslian ajaran gnostik."5

\section{Aplikasi Pengajaran Gnostik}

Pertama, iman yang sederhana pada diri orang percaya perlu disempurnakan melalui ajaran gnosis.

Kedua, mereka juga memakai Firman Allah sebagai asas kepercayaan. contoh Roma 7:13-26, yang sesuai dengan paham mereka yaitu zat benda jahat adanya. Yohanes 1:5 pelajaran tentang gelap dan terang juga sependapat dengan ajaran gnosis.

Ketiga, sistem filsafat juga mempengaruhi pandangan gnostik tentang Yesus. Ada dua pandangan yang berbeda yang satu menyatakan bahwa materi adalah jahat, maka Yesus tidak mungkin benar-benar mengambil rupa manusia, Ia hanya kelihatannya saja berupa manusia dan menderita."6

\section{Pembelaan Dari Umat Kristen}

Irenaeus yang adalah salah satu tokoh polemik, melawan ajaran gnostik dengan menulis buku "melawan bidat-bidat" dalam pemahaman bahwa, ia tidak sependapat dengan Valentinus bahwa ada dua Allah yaitu Allah Perjanjian Lama dan Allah Perjanjian Baru. Menurut Irenaeus pencipta bumi ini bukan Demiurgos melainkan Yesus Kristus sendiri (Kol. 1:16-18; Ibr. 1:2).

Dari penjelasan apa yang diajarkan oleh ajaran gnostik ini, sebenarnya berawal dari pemikiran manusia yang mencoba merumuskan suatu teori tentang bumi, Allah dan Yesus juga pola hidup manusia. Dengan pengajaran yang dilakukan oleh gnostik jelaslah

${ }^{5}$ Th Van Den End, Harta Dalam Bejana (Jakarta: BPK Gunung Mulia, 2009), hlm. 36.

${ }^{6}$ Enns, The Moody Handbook Of Theology, hlm. 34. 
bertentangan dengan ajaran Kristen. Enam point pengajaran gnostik tidak dapat diterima dalam ajaran Kekristenan.

Jelaslah bahwa ajaran gnostik mempengaruhi ajaran kekristenan pada masa Timotius yang melayani di Efesus. Kata pengetahuan dapat diartikan sebagai gnostik. Di dalam pengajarannya nyata bahwa ajaran gnostik tidak sesuai dengan ajaran Alkitab yang walaupun jika diamati bahwa ajaran gnostik semua diambil dari Alkitab.

\section{Dogma Ajaran Kristen}

Untuk menyangkal ajaran dari gnostik yang pada masa itu berkembang maka dalam tulisan ini akan diuraikan tentang dogma ajaran Kristen yang berdasarkan Alkitab.

\section{a. Ajaran Tentang Trinitas}

Orang Kristen percaya tentang Trinitas. Dan dalam kesempatan ini akan diuraikan beberapa pemikiran dari bapa-bapa gereja menjelaskan tentang Trinitas untuk melawan bidat-bidat yang berusaha untuk menyalahkan tentang Allah Kristen diantaranya ialah:

\section{a.1. Yustinus Martyr}

Dalam sejarah gereja nama Yustinus Martyr pada abad ke 2 Masehi cukup kenal dengan beberapa karya-karyanya untuk membela orang Kristen diantaranya adalah tentang Trinitas. Apa pendapat atau pernyataan Yustinus Martyr tenntang Trinitas?

"Yustinus Martyr berusaha melemahkan tuduhan orang kafir yang mengatakan orang Kristen adalah ateis. Yustinus Martyr mengakui bahwa orang-orang Kristen menolak ilah-ilah kafir palsu, tetapi ia selanjutnya berkata orang-orang Kristen tidak menyangkal Allah yang benar yang adalah Bapa keadilan dan kesucian dari segala kebajikan, selanjutnya ia berkata baik Bapa maupu Anak berasal dari padaNya."7

${ }^{7}$ Bernhard Lohse, Pengantar Sejarah Dogma Kristen (Jakarta: BPK Gunung Mulia, 2001), hlm. 54. 
Yustinus Martyr memberikan penjelasan tentang Trinitas dan selanjutnya ia juga mengatakan tentang Roh Kudus adalah bagiam yang sama yang berasal dari Allah.

\section{a.2. Tertullianus}

Karya Tertullianus memperlihatkan makna dalam perkembangan pengajaran tentang formula-formula yang tepat. Tertullianus mengatakan: ia berpegang pada satu subtansi dan tiga pribadi yang berhubungan satu sama lain. Ia berkata tiga pribadi ada dalam satu subtansi namun tetaplah hanya satu Allah."8

Dari penjelasan ini dapat menjelaskan bahwa ajaran gnostik tentang Allah (monoteis) sangatlah bertentangan dengan ajaran Kristen. Selain itu juga bahwa Yesus datang ke dunia hanya dengan tubuh maya sangatlah tidak benar karena Yesus memang datang ke dunia di utus oleh BapaNya (Yoh. 3:16). Dalam Trinitas ini dijelaskan bahwa Allah Bapa, Allah Anak dan Allah Roh Kudus bukan tiga tetapi satu dalam subtansinya.

Dan semua pengajaran dari gnostik adalah sesat dan tidak dapat diterima dalam ajaran yang benar. Dari pandangan sejarah gereja bahwa gnostik memang adalah suatu tantangan yang dihadapi oleh jemaat pada masa itu apalagi pada masa itu selain penganiayaan yang besar-besaran terhadap orang Kristen muncul juga bidat-bidat yang berusaha menyelewengkan ajaran yang benar salah satunya adalah gnostik.

Dari penjelasan ini maka benarlah apa yang pernah Yesus katakan dihadapan pada murid-murid-Nya dalam Matius 16:18 yang mengatakan: "Dan Akupun berkata kepadamu: Engkau ada Petrus dan di atas batu karang ini Aku akan mendirikan jemaat-Ku dan alam maut tidak akan menguasainya. Yesus adalah batu karang itu yang menjadi dasar berdirinya jemaat-Nya. Maka walaupun sekian banyak ajaranajaran atau bidat-bidat bermunculan dengan berbagai ajaran-ajaran yang diajarkan yang kebanyakan adalah mempersalahkan Alkitab dan tidak mengakui kesetaraan antara Allah dan Anak. Tetapi hingga sekarang jemaat Tuhan (Jemaat-Nya) masih ada dan eksis itu bukti

${ }^{8}$ Lohse, Pengantar Sejarah Dogma Kristen, hlm. 56. 
bahwa Yesus adalah batu karang itu dan alam maut tidak akan menguasainya.

\section{DAFTAR PUSTAKA}

Alkitab. Jakarta: Lembaga Alkitab Indonesia, 2015.

Kuiper, B. K. The Church In History. Malang: Penerbit Gandum Mas, 2010.

Enns, Paul. The Moody Handbook Of Theology. Jilid. 2. Malang: Literatur SAAT, 2016.

Prawironegoro, Dr. Darsono. Filsafat Ilmu. Jakarta: Nusantara Consulting, 2011.

Kuhl, Dr Dietrich. Sejarah Gereja. Jilid. 2. Batu: YPPII, 1997.

End, Th Van Den. Harta Dalam Bejana. Jakarta: BPK Gunung Mulia, 2009.

Lohse, Bernhard. Pengantar Sejarah Dogma Kristen. Jakarta: BPK Gunung Mulia, 2001.

Siahaya, Johannis. "Kepemimpinan Kristen Dalam Pluralitas Indonesia." Jurnal Teruna Bhakti 1, no. 1 (2018): 1-16. http://ejournal.stakterunabhakti.ac.id/index.php/teruna/issue/archive.

Wiryadinata, Halim. "A Critical Analysis of Reconciliation Between Muslims and Christians with Special Reference to the Republic of Indonesia." the Glamorgan Univeristy, 2000.

Wiryadinata, Halim. "Mission And Evangelism: African Context." KURIOS (Jurnal Teologi dan Pendidikan Agama Kristen) 3, no. 1 (2015): 1-11. http://www.sttpb.ac.id/e-journal/index.php/kurios. 